\title{
PENGARUH PELATIHAN, KEPEMIMPINAN, DAN MOTIVASI TERHADAP KINERJA KARYAWAN PADA PD BPR BANK JOGJA YOGYAKARTA
}

\author{
Nur Hayati ${ }^{1)}$ \\ Sri Haryani ${ }^{2)}$ \\ ${ }^{1)}$ Alumni Sekolah Tinggi Ilmu Manajemen YKPN Yogyakarta \\ e-mail: shenuerhayati93@gmail.com \\ ${ }^{2)}$ Sekolah Tinggi Ilmu Manajemen YKPN Yogyakarta \\ e-mail: bundaninik@gmail.com
}

\begin{abstract}
The purpose of this study is to analyze the effect of training (X1), leadership (X2), and motivation (X3) on dependent variable employee performance (Y). The population in this study are operational staff in PD BPR Bank Jogja in Yogyakarta. Most of the operational staff of PD BPR Bank Jogja is female and their ages range from 21 to 50 years. Lowest Education of operational staff is Diploma and some of them are Magister (S2). This company is growing as indicated by the increase in the number of staff from time to time. Determination of the number of samples using methods Slovin, samples taken 80. The sampling method using a non-probability sampling with purposive sampling method, the sampling technique is based on the consideration that in accordance with the purpose of research. Collecting data using questionnaires distributed to 80 respondents. The results of multicollinearity, heteroscedasticity, and autocorrelation classical assumption test show that there is no multicollinearity problems among the independent variables, there is no heteroscedasticity in regression models, and there is no autocorrelation. Data were analyzed using multiple linear regression. The results show that the training and motivation have a positive effect on performance, while the leadership has a negative effect on performance. T test results showed that the only variable motivation partially influence on performance, training and leadership variables were partially no effect on employee performance. The F test results showed that the variables of training, leadership, and motivation simultaneously affect the performance of employees.
\end{abstract}

Keywords: training, leadership, motivation, performance

\section{PENDAHULUAN}

Sumberdaya manusia (SDM) mempunyai fungsi yang signifikan dalam suatu perusahaan, terlebih dengan adanya perkembangan bisnis yang semakin pesat, yang menimbulkan tingkat persaingan yang semakin tajam. Pada kondisi ini perusahaan perlu terus menerus mengembangkan kemampuan karyawannya sehingga dapat memenangkan persaingan. Dengan adanya pengembangan karyawan, maka pengetahuan dan keterampilan karyawan akan meningkat sehingga dapat mengurangi produk cacat, mengurangi tingkat kecelakaan kerja, meningkatkan produktivitas kerja, dan meningkatkan kepuasan kerja karyawan. 
Sumberdaya manusia (SDM) menjadi salah satu penggerak perusahaan di mana ia bekerja. Untuk itu perusahaan perlu mengelola dan mempertahankan sumberdayanya yang berkualitas sehingga akan memperlancar kegiatan operasionalnya dan mendukung pencapaian tujuan perusahaan. Dengan demikian dapat dikatakan bahwa saat ini landasan daya saing perusahaan terletak pada aspek sumberdaya manusia. Landasan daya saing yang pada awalnya berasal dari aspek modal dan teknologi sudah bergeser ke aspek sumberdaya manusia.

Sehubungan dengan landasan daya saing dari faktor sumberdaya manusia ini, perusahaan harus mampu mengelola dan mempertahankan karyawannya, sehingga bukan hanya dapat memenangkan persaingan namun sekaligus dapat mencapai tujuan perusahaan. Sumberdaya manusia seperti apa yang mampu memenangkan persaingan sekaligus mencapai tujuan perusahaan? Secara umum karyawan yang mempunyai kinerja yang baik akan mampu memenangkan persaingan dan mencapai tujuan yang telah ditetapkan perusahaan. Kinerja karyawan dapat dilihat dan diukur dari standar kinerja yang ditetapkan oleh perusahaan. Apabila karyawan telah berhasil melaksanakan tugas sesuai dengan standar yang telah ditentukan maka kinerja karyawan tersebut dapat dinilai baik. Menurut Rivai dan Sagala (2013) kinerja merupakan perilaku nyata yang ditampilkan setiap orang sebagai prestasi kerja yang dihasilkan oleh karyawan sesuai perannya dalam perusahaan.

Pelatihan merupakan salah satu faktor yang diyakini manajer dapat mempengaruhi kinerja karyawan. Pelatihan merupakan suatu program yang diharapkan dapat memberikan rangsangan/ stimulus kepada seseorang untuk dapat meningkatkan kemampuan dalam pekerjaan tertentu dan memperoleh pengetahuan umum dan pemahaman terhadap keseluruhan lingkungan kerja. Program pelatihan yang dilakukan oleh perusahaan akan memberikan manfaat bagi perusahaan itu sendiri. Dengan pelatihan akan meningkatkan kemampuan, pengetahuan, serta pemahaman karyawan dalam pekerjaan sesuai dengan bidangnya.

Setelah mendapatkan pengetahuan dan pemahaman melalui program pelatihan, karyawan memerlukan adanya kepemimpinan untuk mengarahkan dan mempengaruhi aktivitas karyawan dalam mencapai tujuan perusahaan dan meningkatkan kinerja karyawan. Kepemimpinan dapat diartikan sebagai proses mengarahkan dan mempengaruhi aktivitas yang berkaitan dengan tugas para anggota kelompok (Sutrisno, 2010).

Faktor lain yang mempengaruhi kinerja karyawan adalah motivasi, yaitu sesuatu yang mendorong seseorang bertindak atau berperilaku tertentu (Hanafi, 2011). Dalam kegiatan bisnis, seorang pemimpin perusahaan perlu untuk memahami motivasi bawahannya. Dari pemahaman motivasi bawahannya ini selanjutnya pemimpin akan memberikan motivasi sesuai dengan kebutuhan karyawan, sehingga kinerja karyawan dapat meningkat secara maksimal sekaligus dapat mencapai tujuan perusahaan.

\section{TINJAUAN PUSTAKA}

\section{Pengaruh Pelatihan terhadap Kinerja Karyawan}

Kaswan (2012) memberikan definisi pelatihan sebagai suatu proses meningkatkan pengetahuan dan keterampilan karyawan. Peningkatan pengetahuan dan keterampilan karyawan ini dimaksudkan agar karyawan dapat mencapai standar kerja yang ditentukan oleh perusahaan. Sementara itu bagi pihak perusahaan sendiri pencapaian standar kerja karyawan akan membantu perusahaan dalam mencapai tujuannya. Sofyandi (2008) menjelaskan 
bahwa pelatihan merupakan suatu program yang diharapkan dapat memberikan rangsangan/ stimulus kepada seseorang untuk dapat meningkatkan kemampuan dalam pekerjaan tertentu dan memperoleh pengetahuan umum dan pemahaman terhadap keseluruhan lingkungan kerja organisasi. Pelatihan dapat menjadi rangsangan atau stimulus bagi karyawan karena peningkatan pengetahuan dan kemampuan itu sendiri menarik bagi karyawan. Dari peningkatan pengetahuan dan kemampuan, selanjutnya akan berdampak pada peningkatan kinerja karyawan. Dengan mengikuti pelatihan karyawan menjadi lebih terampil dalam melaksanakan tugas-tugas yang dibebankan kepadanya. Dalam praktik manajemen perusahaan, peningkatan kinerja karyawan akan mendatangkan reward dalam bentuk finansial maupun non finansial.

Melihat pentingnya pelatihan bagi karyawan maupun perusahaan, manajemen perusahaan akan menyusun proses pelatihan secara sistematis, yang diawali dengan analisis kebutuhan pelatihan, merancang program pelatihan, melaksanakan program pelatihan, dan melakukan penilaian terhadap program pelatihan yang telah dilakukan. Dalam analisis kebutuhan pelatihan perlu dipertimbangkan dari aspek organisasional, aspek pekerjaan dan aspek invidual. Analisis kebutuhan pelatihan dari aspek organisasional perlu dilakukan inventarisasi pengetahuan, keterampilan, dan kemampuan karyawan disesuaikan dengan kebutuhan perusahaan di masa yang datang. Analisis kebutuhan pelatihan dari aspek pekerjaan dilakukan dengan membandingkan pengetahuan, keterampilan, dan kemampuan karyawan dengan persyaratan pekerjaan. Sedang analisis dari aspek individual dilakukan dengan mengidentifikasi individuindividu yang membutuhkan pelatihan.

Dalam proses merancang program pelatihan untuk karyawan, perusahaan perlu memahami kesiapan peserta pelatihan, yang mencakup tingkat keterampilan dasar yang diperlukan dan adanya motivasi dan efikasi diri dari peserta pelatihan. Setelah memahami kesiapan peserta pelatihan, perusahaan menentukan pelatih yang menguasai materi pelatihan yang sesuai dengan yang dibutuhkan.

Dengan proses pelatihan yang disusun secara sistematis diharapkan perusahaan dapat meningkatkan produktivitas, kualitas kerja, sikap moral, semangat kerja, perkembangan pegawai, dan menghindarkan keusangan pengetahuan dan keterampilan karyawan (Mangkunegara, 2013).

Penelitian yang dilakukan Septian (2013) tentang "Pengaruh Pelatihan Terhadap Kinerja Karyawan ERHA Clinic Bandung" menunjukkan bahwa pelatihan berpengaruh signifikan terhadap kinerja karyawan yang ditunjukkan dengan nilai t hitung $(4,006)$ lebih besar dari $t$ tabel (1,685). Penelitian Antori (2014) dengan judul Pengaruh Pelatihan dan Kepemimpinan terhadap Kinerja Karyawan PT Bank Bhakti Daya Ekonomi” menunjukkan bahwa variabel pelatihan berpengaruh signifikan terhadap kinerja karyawan yang ditunjukkan dengan nilai $\mathrm{t}$ hitung $(3,400)$ lebih besar dari t tabel $(1,991)$. Dari kajian teori dan penelitian terdahulu yang dilakukan di atas, maka hipotesis pertama yang diajukan adalah:

$\mathrm{H}_{1}$ : Pelatihan berpengaruh terhadap kinerja karyawan PD BPR Bank Jogja.

\section{Pengaruh Kepemimpinan terhadap Kinerja Karyawan}

Dalam suatu perusahaan, pemimpin mempunyai peran yang berhubungan dengan internal perusahaan maupun eksternal perusahaan. Secara rinci peran pimpinan dapat dikelompokkan ke dalam 3 kategori, peran yang bersifat interpersonal, informasional, dan peran pengambilan keputusan (Sutrisno, 2010). Peran interpersonal menuntut manajer untuk mempunyai 
keterampilan manusiawi, sehingga manajer mampu berinteraksi dengan manusia lain baik yang ada di dalam perusahaan maupun dengan pihak luar perusahaan. Peran informasional berkaitan dengan pemantauan arus informasi di dalam perusahaan maupun diluar perusahaan. Dari berbagai informasi tersebut kemudian diolah untuk selanjutnya didistribusikan atau digunakan sendiri oleh manajer untuk mengambil keputusan. Manajer akan mengambil berbagai keputusan baik yang sifatnya strategis maupun taktis. Selain itu manajer juga bertanggungjawab terhadap seluruh kegiatan perusahaan, termasuk melakukan pengawasan dan tindakan korektif yang dapat merugikan perusahaan.

Dalam praktik kepemimpinan di perusahaan, manajer akan mengarahkan sumberdaya manusia baik secara individu maupun kelompok kearah pencapaian tujuan. Terdapat beberapa tujuan perusahaan antara lain laba, pertumbuhan, dan keberlanjutan (sustainability). Pada umumnya tujuan perusahaan tidak sama dengan tujuan karyawan, bahkan dalam beberapa hal, tujuan perusahaan bertolak belakang dengan tujuan karyawan. Misalnya, karyawan bekerja menginginkan gaji yang tinggi sementara perusahaan menginginkan membayar gaji yang rendah. Pemimpin dapat menggunakan berbagai kekuasaan yang dimilikinya baik yang berasal dari faktor legitimasi, koersif, referensi, keahliannya, maupun yang berasal dari kemampuannya memberikan reward. Dengan menggunakan berbagai kekuasaannya tersebut pimpinan akan mengarahkan karyawannya sehingga karyawan bersedia menggunakan seluruh tenaga dan pikirannya untuk mencapai tujuan perusahaan.

Penelitian yang dilakukan Hendriawan (2014) dengan judul "Pengaruh Gaya Kepemimpinan dan Budaya Organisasi terhadap Kinerja Karyawan pada PT Dwimitra Multiguna Sejahtera di Kabupaten Konawe Utara Propinsi Sulawesi Tenggara" menunjukkan bahwa variabel kepemimpinan berpengaruh signifikan terhadap kinerja karyawan yang ditunjukkan dengan nilai t hitung $(3,148)$ lebih besar dari t tabel $(2,007)$. Berdasar landasan teori dan penelitian terdahulu, maka hipotesis kedua dalam penelitian ini adalah:

$\mathrm{H}_{2}$ : Kepemimpinan berpengaruh terhadap kinerja karyawan PD BPR Bank Jogja.

\section{Pengaruh Motivasi terhadap Kinerja Karyawan}

Motivasi merupakan sesuatu yang mendorong seseorang bertindak atau berperilaku tertentu (Hanafi, 2011). Seorang karyawan yang bekerja dengan motivasi untuk memenuhi keutuhan atau keinginan tertentu pada umumnya lebih bersemangat dan lebih bersedia untuk menggunakan seluruh kemampuannya. Dengan demikian mereka lebih produktif dibanding ketika mereka bekerja tanpa motivasi. Misalnya seseorang mempunyai motivasi naik pangkat, maka dalam bekerja akan menggunakan seluruh daya dan kemampuannya untuk menunjang pencapaian keinginan tersebut.

Terdapat berbagai teori motivasi, antara lain teori motivasi dari Abraham Maslow, yang menyatakan bahwa kebutuhan manusia tersusun dalam bentuk hirarkhi atau berjenjang, dari hirarkhi atau jenjang yang paling rendah kebutuhan fisiologis, kebutuhan keamanan, kebutuhan sosial, kebutuhan penghargaan, dan yang paling tinggi kebutuhan aktualisasi diri (Rivai dan Sagala, 2013). Kebutuhan fisiologis merupakan yang paling penting untuk bertahan hidup dan kesehatan, yang meliputi kebutuhan manusia yang paling dasar yang meliputi kebutuhan makan, minum, pakaian, istirahat dan seks. Sesudah kebutuhan keamanan relatif terpenuhi, muncul kebutuhan keamanan yang terdiri dari kebutuhan rasa aman, perlindungan dari ancaman, bahaya, pertentangan dan lingkungan hidup. Kebutuhan keamanan merupakan kebutuhan 
pertahanan hidup jangka panjang. Kebutuhan sosial meliputi kebutuhan untuk bersahabat, berafiliasi, memiliki pasangan dan keturunan, dan diterima dalam kelompok. Setelah kebutuhan sosial relatif terpenuhi, seseorang akan mencari pemenuhan kebutuhan penghargaan yang meliputi kebutuhan harga diri, status, ketenaran, kemuliaan, pengakuan, perhatian, reputasi, apresiasi, martabat, bahkan dominasi. Apabila seseorang sudah dapat memenuhi kebutuhan penghargaan, mereka siap untuk mencari pemenuhan kebutuhan aktualisasi diri, dengan menggunakan kemampuan, keterampilan, dan potensinya untuk memberikan ide-ide, pendapat, dan penilaian tentang sesuatu hal.

Motivasi dapat muncul dari dalam diri seseorang namun juga dapat berasal dari hal yang berada di luar orang tersebut. Di dalam perusahaan, pemimpin perlu memahami berbagai motivasi yang dapat mendorong karyawannya untuk bertindak atau berperilaku tertentu. Dengan pemberian motivasi yang sesuai dengan kebutuhannya, karyawan dapat meningkatkan kinerjanya sehingga memperoleh hasil yang maksimal dan sekaligus dapat mencapai tujuan perusahaan.

Penelitian yang dilakukan Mahesa (2010) dengan judul "Analisis Pengaruh Motivasi dan Kepuasan Kerja terhadap Kinerja Karyawan dengan Lama Kerja sebagai Variabel Moderating (Studi kasus pada PT Coca-Cola Amatil Indonesia, Central Java)" menunjukkan bahwa variabel motivasi kerja berpengaruh signifikan positif terhadap kinerja karyawan yang ditunjukkan dengan nilai t hitung $(2,110)$ lebih besar dari t tabel $(2,001)$. Berdasar landasan teori dan penelitian terdahulu, maka disusun hipotesis ketiga berikut:

\section{$\mathrm{H}_{3}$ : Motivasi berpengaruh terhadap kinerja karyawan PD BPR Bank Jogja.}

\section{Kinerja Karyawan}

Kinerja karyawan merupakan hal yang sangat penting baik dari sudut pandang karyawan maupun perusahaan. Dari sudut pandang karyawan, kinerja menjadi cerminan kemampuan dan keterampilannya dalam pekerjaan tertentu yang akan berdampak pada reward atau punishment dari perusahaan. Sementara dari sudut pandang perusahaan kinerja karyawan mencerminkan produktivitas perusahaan yang akan mempengaruhi tercapai tidaknya tujuan perusahaan. Untuk mengetahui bagaimana kinerja karyawannya, perusahaan melakukan penilaian atau pengukuran kinerja yang mencakup kemampuan teknis, konseptual, dan hubungan interpersonal. Penilaian atau pengukuran ini akan mengelompokkan karyawan apakah masuk kelompok dibawah standar, sesuai standar atau diatas standar. Karyawan yang kinerjanya di bawah standar dapat menerima punishment dari perusahaan, namun dapat pula perusahaan memberikan pelatihan dan motivasi sehingga kinerjanya meningkat. Sedang karyawan yang kinerjanya melebihi standar akan mendapat reward baik dalam bentuk reward finansial maupun non finansial.

Faktor- faktor yang diyakini manajer dapat mempengaruhi kinerja karyawan jumlahnya relatif banyak, antara lain pelatihan, pendidikan, pengalaman, kepemimpinan, motivasi kompensasi, motivasi, lingkungan kerja dan lain-lain. Mengacu pada ketiga hipotesis di atas dalam penelitian ini diajukan pula hipotesis keempat yang merupakan penggabungan dari ketiga hipotesis sebagai berikut:

$\mathrm{H}_{4}$ : Pelatihan, kepemimpinan, dan motivasi secara simultan berpengaruh terhadap kinerja karyawan PD BPR Bank Jogja. 


\section{METODE PENELITIAN}

\section{Obyek Penelitian}

Pada penelitian ini obyek penelitiannya meliputi pelatihan, kepemimpinan, motivasi, dan kinerja karyawan pada PD BPR Bank Jogja yang beralamat di Jalan Patang Puluhan Nomor 1 Yogyakarta. Subyek penelitian ini merupakan responden dari penelitian ini yaitu karyawan operasional PD BPR Bank Jogja.

\section{Populasi dan Sampel}

Populasi merupakan wilayah generalisasi yang terdiri atas obyek/subyek yang mempunyai kualitas dan karakteristik tertentu yang ditetapkan oleh peneliti untuk dipelajari dan kemudian ditarik kesimpulannya (Sugiyono, 2007). Populasi dalam penelitian ini adalah karyawan operasional pada PD BPR Bank Jogja sejumlah 99 orang.

Menurut Sugiyono (2007) sampel merupakan bagian dari jumlah dan karakteristik yang dimiliki oleh populasi. Sampel diambil menggunakan teknik non probability sampling dengan metode purposive sampling, yaitu teknik pengambilan sampel berdasarkan pertimbangan yang sesuai dengan maksud penelitian, yaitu bahwa yang menjadi sampel adalah karyawan yang pernah diikutsertakan dalam pelatihan. Dengan demikian karyawan tersebut dapat merasakan bagaimana pengaruh pelatihan terhadap kinerjanya. Untuk menentukan besar ukuran sampel yang akan diambil menggunakan metode Slovin, metode ini digunakan untuk menentukan berapa besar minimal sampel yang dibutuhkan jika ukuran populasi sudah diketahui (Wiyono, 2011). Dikarenakan jumlah populasi pada penelitian sudah diketahui berjumlah 99 karyawan, dengan metode Slovin diperoleh jumlah sampel penelitian sebanyak 80 responden.

\section{Metode Pengumpulan Data}

Metode yang digunakan dalam pengumpulan data adalah dengan kuesioner, yaitu teknik pengumpulan data yang dilakukan dengan cara memberi seperangkat pertanyaan atau pernyataan tertulis yang ditujukan kepada responden (Wiyono, 2011). Skala pengukuran dengan menggunakan skala likert, dengan skor 1 sampai dengan 5, di mana skor 5 menunjukkan sangat setuju dengan pertanyaan/pernyataan sedangkan skor 1 sangat tidak setuju. Skala likert digunakan jika peneliti ingin mendapatkan data mengenai bobot setiap jawaban yang diberikan oleh responden.

\section{Metode Analisis}

Tujuan metode analisis data adalah untuk mengintepretasikan dan menarik kesimpulan dari sejumlah data yang terkumpul. Analisis data dengan menggunakan Program SPSS versi 17.0

\section{Uji Instrumen}

Uji validitas dan uji reliabilitas yang dilakukan dalam penelitian ini dimaksudkan agar data yang diperoleh valid dan reliable. Uji validitas merupakan indikator yang menunjukan tingkat seberapa besar item-item instrumen mewakili konsep yang diteliti. Uji validitas yang digunakan dalam penelitian ini adalah uji validasi item, yaitu menguji terhadap kualitas item-itemnya, dengan menghitung korelasi antara setiap item dengan skor total sebagai kriteria validitasnya.

Uji reliabilitas bertujuan untuk menguji sejauh mana alat pengukur dapat dipercaya atau diandalkan. Pengukur reliabilitas dilakukan dengan menggunakan koefisien Alpha Cronbach 
$(\alpha)$. Biasanya reliabilitas minimal 0,5. Uji reliabilitas digunakan untuk mengetahui konsistensi alat ukur, apakah alat pengukur yang digunakan dapat diandalkan dan tetap konsistensi jika pengukuran tersebut diulang di waktu yang akan datang (Wiyono, 2011).

\section{Uji Asumsi Klasik}

\section{Uji Multikolinearitas}

Persyaratan yang harus dipenuhi dalam model regresi adalah tidak ada hubungan linear antar variabel independen dalam model regresi (tidak ada multikolinearitas). Untuk itu dilakukan uji multikolinearitas dengan nilai variance inflation factor (VIF). Apabila VIF kurang dari 5 maka antar variabel independen tidak terjadi masalah multikolinearitas (Wiyono, 2011).

\section{Uji Heteroskedastisitas}

Persyaratan yang harus dipenuhi dalam model regresi adalah tidak adanya varian dari residual untuk semua pengamatan dalam model regresi (tidak ada heteroskedastisitas). Pegujian heteroskedastisitas dengan uji park, yaitu meregresikan nilai residual (Lnei ${ }^{2}$ ) dengan masingmasing variabel independen. Apabila $-\mathrm{t}$ tabel $\leq \mathrm{t}$ hitung $\leq \mathrm{t}$ tabel maka tidak terjadi masalah heteroskedastisitas (Wiyono, 2011).

\section{Uji Autokorelasi}

Persyaratan lain yang harus dipenuhi dalam model regresi adalah tidak adanya korelasi antara residual pada satu pengamatan dengan pengamatan lain pada model regresi. Uji autokorelasi dalam penelitian ini menggunakan uji Durbin-Watson dengan ketentuan apabila d terletak antara dU dan (4-dU) maka tidak terjadi autokorelasi (Wiyono, 2011).

\section{Uji Hipotesis}

\section{Uji t (parsial)}

Uji t atau uji parsial dilakukan untuk mengetahui masing-masing variabel bebas mempunyai pengaruh atau tidak terhadap variabel terikat dan selanjutnya dapat diketahui variabel bebas yang dominan berpengaruh terhadap variabel terikat. Dengan $\alpha=0,05$ pada tingkat kepercayaan 95\%.

\section{Uji F (simultan)}

Uji $\mathrm{F}$ atau uji serentak yaitu uji untuk melihat bagaimanakah pengaruh seluruh variabel bebas secara simultan atau bersama-sama terhadap variabel terikatnya. Dengan $\alpha=0,05$ pada tingkat kepercayaan 95\%.

\section{Regresi Linear Berganda}

Regresi ganda didasari pada hubungan fungsional maupun hubungan kausal dari dua atau lebih variabel independen dengan satu variabel dependen. Adapun persamaannya ditulis berikut ini (Wiyono, 2011):

$\mathrm{y}=\mathrm{a}+\mathrm{b} \cdot \mathrm{X}_{1}+\mathrm{c} \cdot \mathrm{X}_{2}+\mathrm{d} \cdot \mathrm{X}_{3}+\mathrm{e}$

Dimana:

y $=$ Kinerja Karyawan

a $=$ Konstanta 
$\mathrm{b}=$ Koefisien Pelatihan

c $=$ Koefisien Kepemimpinan

$\mathrm{d}=$ Koefisien Motivasi

$\mathrm{X}_{1}=$ Pelatihan

$\mathrm{X}_{2}=$ Kepemimpinan

$\mathrm{X}_{3}=$ Motivasi

e $=$ Random error atau gangguan di luar penelitian

\section{HASIL DAN PEMBAHASAN}

Dari hasil kuesioner yang telah disebar kepada 80 responden didapat hasil analisis data sebagai berikut.

\section{Uji Validitas}

Uji validitas digunakan untuk mengukur valid tidaknya suatu kuesioner. Hasil uji validitas pada penelitian ini adalah sebagai berikut:

Tabel 1. Hasil Uji Validitas

\begin{tabular}{ccccc}
\hline Variabel & Pertanyaan & r hitung & r tabel & Keterangan \\
\hline & 1 & 0,477 & 0,2199 & Valid \\
2 & 0,507 & 0,2199 & Valid \\
3 & 0,499 & 0,2199 & Valid \\
& 4 & 0,581 & 0,2199 & Valid \\
& 5 & 0,533 & 0,2199 & Valid \\
Pelatihan (X1) & 6 & 0,437 & 0,2199 & Valid \\
& 7 & 0,614 & 0,2199 & Valid \\
& 8 & 0,436 & 0,2199 & Valid \\
& 9 & 0,670 & 0,2199 & Valid \\
& 10 & 0,436 & 0,2199 & Valid \\
& 11 & 0,655 & 0,2199 & Valid \\
& 12 & 0,483 & 0,2199 & Valid \\
& 13 & 0,442 & 0,2199 & Valid \\
\hline \multirow{5}{*}{ Kepemimpinan (X2) } & 14 & 0,888 & 0,2199 & Valid \\
& 15 & 0,756 & 0,2199 & Valid \\
& 16 & 0,776 & 0,2199 & Valid \\
& 17 & 0,838 & 0,2199 & Valid \\
& 18 & 0,875 & 0,2199 & Valid \\
& 19 & 0,824 & 0,2199 & Valid \\
& 20 & 0,792 & 0,2199 & Valid \\
& 21 & 0,916 & 0,2199 & Valid \\
\hline
\end{tabular}




\begin{tabular}{ccccc}
\hline & 22 & 0,635 & 0,2199 & Valid \\
& 23 & 0,785 & 0,2199 & Valid \\
Motivasi (X3) & 24 & 0,775 & 0,2199 & Valid \\
& 25 & 0,830 & 0,2199 & Valid \\
& 27 & 0,680 & 0,2199 & Valid \\
Kinerja & 28 & 0,767 & 0,2199 & Valid \\
Karyawan (Y) & 29 & 0,776 & 0,2199 & Valid \\
& 30 & 0,719 & 0,2199 & Valid \\
\hline 31 & 0,726 & 0,2199 & Valid \\
& 32 & 0,976 & 0,2199 & Valid \\
& 33 & 0,765 & 0,2199 & Valid \\
& 34 & 0,729 & 0,2199 & Valid \\
& 36 & 0,848 & 0,2199 & Valid \\
& 37 & 0,799 & 0,2199 & Valid \\
& 38 & 0,727 & 0,2199 & Valid \\
& 39 & 0,811 & 0,2199 & Valid \\
& 0,739 & 0,2199 & Valid \\
\hline
\end{tabular}

Sumber: Olah data SPSS 17.0, 2015

Hasil uji validitas di atas menyatakan bahwa nilai $r$ hitung setiap indikator variabel pelatihan, kepemimpinan, motivasi, dan kinerja karyawan lebih besar dibandingkan $r$ tabel $(0,2199)$. Dengan demikian semua indikator pada kuesioner yang digunakan untuk mengambil data primer dalam penelitian ini dinyatakan valid untuk digunakan menjadi alat ukur variabel.

\section{Uji Reliabilitas}

Jumlah responden pada penelitian ini sebanyak 80. Nilai r tabel dengan tingkat signifikansi 0,05 adalah 0,2199 dengan menggunakan uji 2 sisi. Adapun uji reliabilitas masing-masing variabel sebagai berikut:

Tabel 2. Hasil Uji Reliabilitas

\begin{tabular}{lccc}
\hline \multicolumn{1}{c}{ Variabel } & Cronbach's Alpha & r tabel & Keterangan \\
\hline Pelatihan (X1) & 0,775 & 0,2199 & Reliabel \\
Kepemimpinan (X2) & 0,936 & 0,2199 & Reliabel \\
Motivasi (X3) & 0,869 & 0,2199 & Reliabel \\
Kinerja Karyawan (Y) & 0,921 & 0,2199 & Reliabel \\
\hline
\end{tabular}

Sumber: Olah data SPSS 17.0, 2015

Hasil uji reliabilitas diatas menunjukkan nilai Cronbach's Alpha untuk masing-masing indikator lebih besar dibanding $r$ tabel 0,2199. Dapat disimpulkan bahwa semua indikator yang meliputi pelatihan, kepemimpinan, motivasi, dan kinerja karyawan reliabel. 


\section{Uji Asumsi Klasik}

\section{Uji Multikolinearitas}

Nilai variance inflation factor (VIF) variabel pelatihan sebesar 3,679, variabel kepemimpinan sebesar 2,430, dan variabel motivasi sebesar 3,372. Dari ketiga variabel tersebut masing-masing hasilnya lebih kecil dari 5, sehingga dapat disimpulkan antar variabel independen tidak terjadi masalah multikolinearitas.

Tabel 3. Hasil Uji Multikolinearitas

\begin{tabular}{llcc}
\hline \multirow{2}{*}{ Model } & \multicolumn{2}{c}{ Collinearity Statictics } \\
\cline { 3 - 4 } & & Tolerance & VIF \\
\hline $1 \quad$ (Constant) & & \\
& Pelatihan & 0,285 & 3,679 \\
& Kepemimpinan & 0,432 & 2,430 \\
& Motivasi & 0,307 & 3,372 \\
\hline
\end{tabular}

Sumber: Olah data SPSS 17.0, 2015

\section{Uji Heteroskedastisitas}

Hasil uji heteroskedastisitas menunjukkan nilai thitung variabel pelatihan sebesar 1,024, variabel kepemimpinan sebesar -0,346, dan variabel motivasi sebesar 0,257. Sedangkan $t$ tabel dengan $\mathrm{df}=\mathrm{n}-2$ atau 80-2 $=78$, adalah sebesar 1,6646. Karena nilai t hitung berada pada $-\mathrm{t}$ tabel $\leq \mathrm{t}$ hitung $\leq \mathrm{t}$ tabel, maka dapat disimpulkan bahwa tidak ditemukan masalah heteroskedastisitas pada model regresi.

\section{Tabel 4. Hasil Uji Heteroskedastisitas}

\section{Coefficients $^{\mathrm{a}}$}

\begin{tabular}{llcccccc}
\hline \multirow{2}{*}{ Model } & \multicolumn{2}{c}{ Unstandardized Coeffficients } & Standadrdized Coefficients & & \\
\cline { 2 - 5 } & & B & Std Error & Beta & & Sig. \\
\hline 1 & (Constant) & 8,662 & 10,859 & & 0,677 & 0,453 \\
& Ln_Pelatihan & 3,410 & 5,014 & 0,297 & & 1,024 & 0,682 \\
& Ln_Kepemimpinan & $-0,918$ & 4,713 & $-0,152$ & & $-0,346$ & 0,235 \\
& Ln_Motivasi & 0,547 & 5,146 & 0,354 & 0,257 & 0,521 \\
\hline
\end{tabular}

a. Dependent Variabel: Lnei2

Sumber: Olah data SPSS 17.0, 2015

\section{Uji Autokorelasi}

Dari hasil uji di atas, diperoleh nilai DW 1,679. Sedangkan dari tabel signifikansi 0,05 dengan jumlah data $(n)=80$ dan jumlah variabel independen $(k)=3$, menghasilkan dL sebesar 1,560 dan dU sebesar 1,715. Karena nilai DW berada pada daerah dU dan 4-dU, maka dapat disimpulkan bahwa tidak ada autokorelasi. 
Tabel 5. Hasil Uji Autokorelasi

Model Summary

\begin{tabular}{cccccc}
\hline Model & R & R Square & Adjusted R Squere & Std Error of the Estimate & Durbin Watson \\
\hline $\mathbf{1}$ & $0,806^{\mathrm{a}}$ & 0,743 & 0,721 & 3,23183 & 1,679 \\
\hline
\end{tabular}

a. Predictors: (Constant), pelatihan, kepemimpinan, motivasi

b. Dependent variable: kinerja

\section{Uji Hipotesis}

Hipotesis merupakan pembatas ruang lingkup serta pengarah dari suatu penelitian. Hipotesis akhirnya diuji kebenarannya oleh hasil dari penelitian. Hipotesis diuji dengan menggunakan dua metode yakni uji t dan uji F.

\section{Uji t}

Uji t dilakukan untuk mengetahui pengaruh pelatihan, kepemimpinan, dan motivasi secara parsial terhadap kinerja karyawan. Hasil dari uji t pada penelitian ini adalah sebagai berikut:

Tabel 6. Hasil Uji t

Coefficients $^{a}$

\begin{tabular}{llcccccc}
\hline \multirow{2}{*}{ Model } & \multicolumn{2}{c}{ Unstandardized Coefficients } & Standardized Coefficients & \multirow{2}{*}{$\mathbf{t}$} & \multirow{2}{*}{ Sig. } \\
\cline { 2 - 5 } & & $\mathbf{B}$ & Std. Error & Beta & & \\
\hline 1 & (Constant) & 8.740 & 4.946 & & 1.767 & .081 \\
& Pelatihan (X1) & .113 & .098 & .107 & 1.163 & .248 \\
Kepemimpinan (X2) & -.023 & .077 & -.027 & -.308 & .759 \\
& Motivasi (X3) & .835 & .108 & .675 & 7.729 & .000 \\
\hline
\end{tabular}

a. Dependent Variable: Kinerja karyawan

Sumber: Olah data SPSS 17.0, 2015

Dari perhitungan pada Tabel 6 di atas hasilnya dapat dinyatakan sebagai berikut:

a. Pengaruh pelatihan terhadap kinerja karyawan

Nilai signifikansi t untuk variabel pelatihan (X1) sebesar 0,248 lebih besar dari nilai taraf signifikansi $(0,05)$, berarti secara parsial tidak ada pengaruh antara variabel pelatihan terhadap variabel kinerja karyawan. Apabila PD BPR Bank Jogja bermaksud meningkatkan kinerja karyawan, hanya dengan memberikan pelatihan saja (tidak disertai dengan program yang lain), maka kinerja karyawan tidak akan meningkat secara signifikan.

b. Pengaruh kepemimpinan terhadap kinerja karyawan

Nilai signifikansi t untuk variabel kepemimpinan (X2) sebesar 0,759 lebih besar dari nilai taraf signifikansi $(0,05)$, berarti secara parsial tidak ada pengaruh antara variabel kepemimpinan terhadap variabel kinerja karyawan. Apabila PD BPR Bank Jogja bermaksud meningkatkan kinerja karyawan, hanya dengan menggunakan variabel kepemimpinan saja, (tidak disertai dengan program yang lain), maka kinerja karyawan tidak akan meningkat secara signifikan. 
c. Pengaruh motivasi terhadap kinerja karyawan

Nilai signifikansi t untuk variabel motivasi (X3) sebesar 0,000 lebih kecil dari nilai taraf signifikansi $(0,05)$. Artinya, secara parsial ada pengaruh antara variabel motivasi terhadap variabel kinerja karyawan. Variabel motivasi (X3) secara parsial berpengaruh signifikan dalam meningkatkan kinerja karyawan. Peningkatan kinerja karyawan dapat dilakukan hanya dengan menggunakan variabel motivasi saja, baik dalam bentuk motivasi fisiologis, keamanan, sosial, pengakuan, maupun aktualisasi.

\section{Uji F}

Uji $\mathrm{F}$ dilakukan untuk mengetahui pengaruh pelatihan, kepemimpinan, dan motivasi secara simultan terhadap kinerja karyawan. Hasil pengujian uji $\mathrm{F}$ pada penelitian ini adalah sebagai berikut:

Tabel 7. Hasil Uji F

ANOVA $^{b}$

\begin{tabular}{lccccc}
\hline Model & Sum of Squares & df & Mean Square & F & Sig. \\
\hline Regression & 959.486 & 3 & 319.829 & 26.469 & $.000^{\mathrm{a}}$ \\
Residual & 918.314 & 76 & 12.083 & & \\
Total & 1877.800 & 79 & & & \\
\hline
\end{tabular}

a. Predictors: (Constant), Pelatihan, Kepemimpinan, Motivasi

b. Dependent Variable: Kinerja

Sumber: Olah data SPSS 17.0, 2015

Pengujian dalam penelitian ini menggunakan uji dua sisi dengan tingkat signifikasi $(a)$ $5 \%$. Hasil uji F pada tabel 7 menunjukkan nilai probabilitas $\mathrm{P}_{\text {value }}$ (sig) sebesar 0,000 kurang dari 0,05 (tingkat signifikansi 5\%) yang berarti bahwa variabel bebas yang terdiri dari variabel pelatihan, kepemimpinan, dan motivasi secara simultan berpengaruh terhadap kinerja karyawan.

\section{Regresi Berganda}

Analisis regresi berganda menunjukan pengaruh atau hubungan variabel bebas pelatihan (X1), kepemimpinan (X2), dan motivasi (X3) terhadap variabel terikat kinerja karyawan (Y). Hasil regresi berganda pada penelitian ini adalah sebagai berikut:

Tabel 8. Hasil Uji Regresi Berganda

$$
\text { Coefficients }^{\mathrm{a}}
$$

\begin{tabular}{|c|c|c|c|c|c|c|}
\hline & \multirow{2}{*}{ Model } & \multicolumn{2}{|c|}{ Unstandardized Coefficients } & \multirow{2}{*}{$\begin{array}{c}\text { Standardized Coefficients } \\
\text { Beta } \\
\end{array}$} & \multirow{2}{*}{$\mathbf{t}$} & \multirow{2}{*}{ Sig. } \\
\hline & & B & Std. Error & & & \\
\hline \multirow{4}{*}{1} & (Constant) & 8.740 & 4.946 & & 1.767 & .081 \\
\hline & Pelatihan (X1) & .113 & .098 & .107 & 1.163 & .248 \\
\hline & Kepemimpinan (X2) & -.023 & .077 & -.027 & -.308 & .759 \\
\hline & Motivasi (X3) & .835 & .108 & .675 & 7.729 & .000 \\
\hline
\end{tabular}

Sumber: Olah data SPSS 17.0, 2015 
Berdasar tabel diatas, maka dapat disajikan persamaan regresi berganda sebagai berikut: Keterangan:

$\mathrm{Y}=8,740+0,113 \mathrm{X}_{1-} 0,023 \mathrm{X}_{2}+0,835 \mathrm{X}_{3}$

Y : Kinerja karyawan

$\mathrm{X}_{1}$ : Pelatihan

$\mathrm{X}_{2}$ : Kepemimpinan

$\mathrm{X}_{3}$ : Motivasi

Dari hasil persamaan regresi berganda diatas, maka dapat diartikan sebagai berikut:

a. Nilai konstanta sebesar 8,740, artinya jika semua variabel independen X1, X2, X3 sama dengan 0 artinya tidak ada pelatihan, kepemimpinan, dan motivasi, maka karyawan masih memiliki tingkat kinerja sebesar (Y) sebesar 8,740 satuan.

b. Koefisien regresi variabel pelatihan (X1) sebesar 0,113 menunjukkan bahwa setiap kenaikan pelatihan sebesar 1 satuan, dengan asumsi variabel kepemimpinan (X2) dan motivasi (X3) tetap/konstan maka akan meningkatkan kinerja karyawan (Y) sebesar 0,113 satuan.

c. Koefisien regresi variabel kepemimpinan(X2) sebesar -0,023 menunjukkan bahwa setiap penambahan variabel kepemimpinan sebesar 1 satuan, dengan asumsi variabel pelatihan (X1) dan variabel motivasi (X3) tetap/konstan, maka kinerja karyawan akan mengalami penurunan sebesar 0,023 satuan.

d. Koefisien regresi variabel motivasi (X3) sebesar 0,835 menunjukkan bahwa setiap kenaikan variabel motivasi $\left(\mathrm{X}_{3}\right)$ sebesar 1 satuan, maka akan terjadi peningkatan kinerja karyawan sebesar 0,835 satuan.

Tabel 9. Model Summary

\begin{tabular}{ccccc}
\hline Model & R & R Square & Adjusted R Square & Std error of the estimate \\
\hline 1 & $.715^{\mathrm{a}}$ & .511 & .492 & 3.476 \\
\hline
\end{tabular}

a. Predictor: (constant), pelatihan, kepemimpinan, motivasi

Pada tabel model summary nilai $R$ square sebesar 0,511 atau $51,1 \%$ artinya bahwa $51,1 \%$ variabel kinerja karyawan (Y) dapat dijelaskan oleh variabel pelatihan, kepemimpinan, dan motivasi (X). Sedangkan sisanya sebesar 48,9\% dijelaskan oleh variabel-variabel lain yang tidak termasuk dalam penelitian ini seperti lingkungan kerja, kompensasi, pengawasan, disiplin kerja dan lain sebagainya.

\section{SIMPULAN DAN SARAN}

\section{Simpulan}

Berdasarkan hasil penelitian yang dilakukan pada perusahaan PD BPR Bank Jogja, maka dapat diambil kesimpulan sebagai berikut:

1. Secara simultan, variabel pelatihan, kepemimpinan, dan motivasi berpengaruh terhadap kinerja karyawan PD BPR Bank Jogja Yogyakarta. Hal ini ditunjukkan dengan nilai signifikan sebesar 0,000, lebih kecil dari signifikansi 0,05 . 
2. Secara parsial, variabel pelatihan dan kepemimpinan tidak berpengaruh terhadap kinerja karyawan, sedangkan variabel motivasi secara parsial berpengaruh terhadap kinerja karyawan. Dapat disimpulkan dengan adanya peningkatan motivasi maka akan meningkatkan kinerja karyawan.

3. Berdasar analisis regresi linear berganda menunjukkan bahwa di antara variabel pelatihan, kepemimpinan dan motivasi yang paling besar pengaruhnya terhadap kinerja adalah variabel motivasi yang ditunjukkan dengan koefisien korelasi motivasi sebesar 0,835 .

4. Nilai $R$ square sebesar 0,511 atau $51,1 \%$, artinya sebesar $51,1 \%$ variabel dependen (kinerja karyawan) dapat dijelaskan oleh variabel independen yang terdiri dari pelatihan, kepemimpinan, dan motivasi. Sedangkan sebesar 48,9\% dijelaskan oleh variabel-variabel lain yang tidak dimasukkan dalam penelitian seperti lingkungan kerja, kompensasi, pengawasan, disiplin kerja dan lain sebagainya.

\section{Saran}

Beberapa saran yang dapat diberikan oleh peneliti kepada perusahaan untuk meningkatkan kinerja adalah sebagai berikut:

1. Untuk meningkatkan kinerja karyawan, perusahaan perlu mempertahankan dan meningkatkan motivasi.

2. Meskipun secara parsial variabel independen pelatihan dan kepemimpinan tidak berpengaruh terhadap kinerja karyawan, namun secara simultan berpengaruh, maka perusahaan tetap perlu memperhatikan pelatihan dan kepemimpinan terhadap karyawan PD BPR Bank Jogja Yogyakarta.

3. Untuk penelitian selanjutnya diharapkan dapat menambah variabel lain yang merupakan faktor-faktor yang mempengaruhi kinerja karyawan.

\section{REFERENSI}

Antori. 2014. Pengaruh Pelatihan dan Kepemimpinan terhadap Kinerja Karyawan pada PT Bank Bhakti Daya Ekonomi. Skripsi. STIM YKPN Yogyakarta.

Hanafi, Mamduh M. 2011. Manajemen. Yogyakarta: Unit Penerbit dan Percetakan STIM YKPN Yogyakarta.

Hendriawan. 2014. Pengaruh Gaya Kepemimpinan dan Budaya Organisasi terhadap Kinerja Karyawan pada PT Dwimitra Multiguna Sejahtera di Kabupaten Konawe Utara Propinsi Sulawesi Tenggara. Skripsi. Universitas Hasanudin Makasar. Http:// repository.unhas.ac.id/handle/123456789/10035. Diakses 12 November 2014 jam 13.05 .

Kaswan. 2012. Pelatihan dan Pengembangan untuk Meningkatkan Kinerja SDM. Bandung: Alfabeta.

Mahesa, Diwar. 2010. Analisis Pengaruh Motivasi terhadap Kinerja Karyawan dengan Lama Kerja sebagai Variabel Moderating (Studi Kasus Pada PT Coca Cola Amatik Indonesia, Central Java). Skripsi. Universutas Diponegoro Semarang. 
Mangkunegara, Anwar Prabu. 2013. Manajemen Sumberdaya Manusia Perusahaan. Bandung: PT Remaja Rosda Karya.

Rivai, Veithzal dan Ella Jauvani Sagala. 2013. Manajemen Sumberdaya Manusia Untuk Perusahaan. Jakarta: PT Raha Grafindo Persada.

Sedarmayanti. 2013. Manajemen Sumberdaya Manusia. Bandung: PT Refika Aditama.

Septian Reza. 2013. Pengaruh Pelatihan Terhadap Kinerja Karyawan ERHA Clinic Bandung. Skripsi. Universitas Widyatama.

Sofyandi, Herman. 2008. Manajemen Sumberdaya Manusia. Yogyakarta: Graha Ilmu.

Sugiyono. 2007. Metode Penelitian Bisnis. Bandung: CV Alfabeta.

Sutrisno, Edy. 2010. Manajemen Sumberdaya Manusia. Jakarta: Kencana Perdana Media Group.

Wiyono, Gendro. 2011. Merancang Penelitian Bisnis dengan Alat Analisis SPSS 17.0 \& SmartPLS 2.0. Yogyakarta: UPP STIM YKPN Yogyakarta. 
